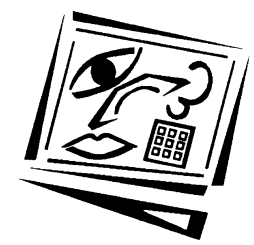

\title{
Web-based lecture technologies: Highlighting the changing nature of teaching and learning
}

\author{
Greg Preston \\ The University of Newcastle \\ Rob Phillips \\ Murdoch University \\ Maree Gosper, Margot McNeill, Karen Woo \\ Macquarie University \\ David Green \\ Flinders University
}

\begin{abstract}
There is now widespread recognition of the changing nature of students in higher education: they are demographically diverse, have extensive external time demands, and expect greater flexibility and support during their programs. As a consequence of this and other changes to the higher education sector, many universities worldwide have introduced a range of information and communication technologies to provide students with flexible options for study. Included in these options are web-based lecture technologies (WBLT), designed to digitally record lectures for delivery over the web. This paper reports on recent Australian research into the impact of WBLT on learning and teaching which indicates that, while many academics recognise the changing nature and needs of their students and have introduced WBLT as a consequence, many have not reconceptualised their curriculum and its delivery to meet these changing circumstances. The central premise in this paper is that the introduction of WBLT has been disruptive in nature and has provided a lens with which to view several emerging issues: the blurring of study patterns between internal and external enrolment modes; the role of lectures in technology rich environments; and the changing nature of teaching when technologies are introduced into the curriculum.
\end{abstract}

\section{Introduction}

Web-based lecture technologies (WBLT) have gained popularity in many higher education institutions as tools to provide flexible access to lectures for students. These technologies can be described as distributed recording systems for digitally capturing face to face lectures for web delivery in streaming, downloadable or podcasting formats. Lectopia (previously known as iLecture, is now owned and marketed by Echo360) is an example of this type of technology (Lectopia, 2007) which is in use at three of the four universities which took part in this study.

This paper reports on parts of a larger study, across four Australian universities exploring how WBLT can best support learning and teaching (Gosper, McNeill, Preston, Phillips, Green \& Woo, 2008). 


\section{Background: WBLT and the changing university context}

In many universities, both in Australia and overseas, WBLT have been introduced in recognition of the need for flexible learning options for their on campus or 'internal' students. For example, iLecture was first designed to support students at a small, remote campus of The University of Western Australia. Some of the early uptake of iLecture at other universities was to replace the cumbersome cassette recordings of lectures which were sent to distance education students through the post. Thus new tools have provided students with choices in how they access lecture content and how they use that content to support their learning.

Not surprisingly, WBLT are gaining in popularity, particularly with students finding their needs for flexibility not being met by 'traditional on campus teaching paradigms' (Lefoe \& Albury, 2004). With increased demands posed by work and family commitments (Anderson, 2006; McInnis \& Hartley, 2002), recent studies have confirmed students' appreciation of the convenience and flexibility offered by anytime, anywhere access to lectures (Fardon, 2003; McNeill, Woo, Gosper, Phillips, Preston \& Green, 2007; Williams \& Fardon, 2007). Similar results are also emerging from studies which use data from usage logs for specific web-based lecture technologies (von Konsky, Ivins \& Gribble, 2009).

In addition to flexibility, students are usually positive about the impact these technologies have on their learning (Williams \& Fardon, 2005; Woo, Gosper, McNeill, Preston, Green \& Phillips, 2008). Recent studies (McElroy \& Blount, 2006; Soong, Chan, Cheers \& $\mathrm{Hu}, 2006)$ found students agreed that lecture recordings enhanced the course when compared to other courses without this facility. Additionally, there is evidence that WBLT are used by students as a study tool to complement face to face lectures (Signor, 2003; Williams \& Fardon, 2007). Students reported using WBLT to support their learning by checking over notes, by reviewing difficult concepts, by revising for exams and by listening to missed lectures (McElroy \& Blount, 2006). Thus, as suggested by Craig, Wozniak, Hyde \& Burn (2009), distinct and diverse patterns of student usage are emerging.

The response to WBLT by academic teaching staff has been less consistent than their student counterparts. Some lecturers have adopted WBLT as tools which can be used to enhance student learning and flexibility (Williams \& Fardon, 2007) while other lecturers have criticised WBLT as reinforcing lecturing as a primary learning activity (Donnan, Kiley \& McCormack, 2004) or contributing to students' low attendance (Williams \& Fardon, 2007; Phillips, Gosper, McNeill, Woo, Preston \& Green, 2007). Academics have acknowledged the equity advantages inherent in the adoption of WBLT (Chang, 2007) however, staff have simultaneously reported lower ratings for both satisfaction and importance for online learning environments generally (Palmer \& Holt, 2009).

A picture therefore emerges of universities introducing tools such as WBLT as part of their attempts to adapt to the changing needs of their students, which have then enjoyed a positive reception by students for their added flexibility. The picture also shows academic teaching staff as being less positive as they struggle to deal with the complexities of the changing environment in which they work. 
As WBLT and other technologies have been introduced, they have provided a lens to view the intensifying complexity of the teaching and learning context. Several key themes emerging from the research using this lens are explored in relation to:

- the blurring of traditional study patterns between internal and external enrolment modes;

- the role of lectures in technology rich environments; and

- the changing nature of teaching when technologies are introduced into the curriculum.

\section{The research}

The study employed a mixed methods approach (Creswell, 2003), drawing on quantitative and qualitative data obtained from both students and lecturers who used WBLT. Four main data collection activities were undertaken during the study: a student survey, a staff survey, in depth interviews with both students and lecturers, and a set of case studies designed to investigate issues in depth, or implement possible strategies.

The student survey collected data from 815 students across four Australian university campuses, on four specific areas. The first part of the survey asked students about their experience of WBLT in the context of a specific subject. In the second part, students were given the Revised Two-factor Study Process Questionnaire (Biggs, Kember \& Leung, 2001 ) to explore relationships between deep and surface approaches to learning. The third part of the questionnaire asked students about their overall experience of WBLT in their university learning. In the final part, students' demographic information was collected.

The survey for lecturing staff was designed to correspond where possible with the student survey, so that results could be compared. The survey collected data from 155 Australian academics on three specific areas in relation to lecturers and their use of WBLT:

1. the teaching and curriculum context, including details of delivery mode and discipline area;

2. the reasons for using WBLT and the strategies adopted; and

3. their perceptions of the effect of WBLT on lecture attendance and communication patterns between themselves and their students.

In addition, Trigwell \& Prosser's (2004) Approaches to Teaching Inventory was included to provide insight into lecturers' perspectives of their teaching philosophy.

In order to provide a more contextualised view of the issues emerging from the surveys, staff and student respondents were invited to participate in interviews to develop vignettes. Participants self nominated, and semi-structured interviews were used to gather more detail about their specific experiences using the technologies. In total 19 vignettes were developed, illustrating examples of current practices of how staff and students use WBLT.

The third phase of the study involved a series of six case studies, designed to be either investigative or developmental. Academics known to use web-based lecture technologies in innovative ways were invited to participate in the case studies to 
explore the issues emerging from the earlier phases or implement strategies to improve practice.

In addition to the standard statistical and qualitative data analysis, traditional iterative mixed methods approaches to the triangulation of data sets were adopted throughout the study. For example, interview data was used to both contextualise and comprehend the survey responses, and acted as a focus for alternative interpretations of the existing quantitative data sets. More details about the project's methodology and the statistical analyses, along with the vignettes and case studies, are available from the project website: http:/ / www.cpd.mq.edu.au/teaching/wblt/ overview.htm

\section{WBLT and the blurring of internal and external study patterns}

Student respondents from across all four universities liked WBLT and found that it helped them to learn. Seventy-six percent $(76 \%)$ reported they had a positive experience with WBLT almost always or frequently. When asked if they thought that using WBLT made it easier to learn, $80 \%$ of respondents agreed that it had in either a significant or a moderate way; $13 \%$ were not sure if there was any change, and only $7 \%$ felt it didn't help or was detrimental.

When asked if they thought using WBLT helped them achieve better results, $67 \%$ of respondents agreed that it had, in either a significant or a moderate way; $23 \%$ were not sure if there was any change and only $10 \%$ felt it didn't help or was detrimental.

Students appreciated WBLT as providing an additional study tool to assist their learning although face to face lectures were still seen as valuable. Seventy six percent $(76 \%)$ of students indicated they used WBLT to study for exams and the same number indicated they used the recordings to revisit complex ideas and concepts. Sixty three percent $(63 \%)$ of students indicated they used WBLT to take notes from the lectures. It is clear that, whether attending the face to face sessions or not, students perceived the recordings provided opportunities to support learning of the content presented in lectures.

Technologies such as WBLT have often been introduced as an enhancement for those students enrolled as distance education or 'external' students. The sense of isolation experienced by external students is well-represented in the literature (Galusha, 1997; Simpson, 2000) and WBLT can assist in breaking down this isolation and motivating students to learn, particularly if lecturers acknowledge and cater for the presence of students other than those visible in the lecture room. Although it has long been acknowledged that external students need flexibility, the data indicates that students enrolled in internal mode also appreciate this aspect of WBLT. From the survey responses, $56 \%$ of students indicated that they didn't attend at least some of the face to face lectures that were available. Of these students, $75.3 \%$ indicated this was because they 'couldn't attend'.

The need for flexibility emerged in the open ended comments from students enrolled in both internal and external modes. For example, one of the external students interviewed for the project had two young children and found it very useful to listen to the lecture recordings on an iPod whilst her daughters were having ballet lessons. She commented that WBLT made it possible for her to keep up to date with the course. However, the same need for flexibility was encountered by an internal student who 
lived over an hour away from campus and needed to drop off her children to school at a time coinciding with a lecture.

The use of WBLT didn't necessarily exclude lecture attendance, as many students in both the surveys and interviews indicated that they often 'doubled up' by attending lectures and listening to the recordings. While they appreciated the flexibility and convenience of WBLT, students in the survey did like lectures. Amongst the reasons cited were that they found them motivating, they valued contact with the lecturers and their peers and they found the visual aids helpful. Many of the comments from those enrolled in external modes indicate use of WBLT to increase their sense of participation in lectures, and as a form of engagement with their lecturers and peers.

Although WBLT were usually introduced to capture lecture content, some external students saw their use as reducing the sense of isolation and helping connect them to their lecturers and to each other, particularly when used in conjunction with other social technologies. As one external student commented:

Every lecture should be available on [WBLT] and I would not mind if the tutorials were as well... With modern day technology external students could send their presentation taped and have discussion via Skype... So we would not really be 'external'.

It is clear that the possibilities brought about by WBLT are challenging the traditional 'boundaries' between internal and external modes of study (Woo et al., 2008). Where once academics operated under the expectation that those students enrolled as on campus students would attend most face to face lectures and those enrolled in external mode would not, these distinctions are becoming blurred. Blended learning models supported by a range of technologies have emerged which combine, for example, face to face lectures and/or tutorials with supplementary resources and discussion forums available online (Lefoe \& Hedberg, 2006; Phillips, 2005; Phillips, 2006). As suggested by Lefoe and Albury (2004), 'the teaching, delivery methods and resources once used only for one area are now used to support learning in both' (2004, p. 1).

The consolidation of activities and resources for internal external students combined with blurring study patterns and behaviours of both groups, highlights the need for staff to reflect on whether the design of the curriculum and their expectations of students' study behaviours matches the needs and expectations of their students. The 2009 Horizon Report (Johnson, Levine \& Smith, 2009) poses the challenge that:

Students are different, but a lot of educational material is the same. (p.6)

\section{The changing role of lectures}

While it is well recognised that student attendance at lectures has been reducing over recent years (Maag, 2006; Massingham \& Herrington, 2006; Phillips et al., 2007), it seems that WBLT has acted as a 'lens', focusing attention on this trend and making student absence more obvious to lecturers. The staff survey asked for a Likert scale rating of the statement Student attendance in my lecture has decreased as a result of using WBLT. Just over half (55\%) of the respondents felt that WBLT had resulted in decreased lecture attendance and many of the open-ended comments and interviews reinforced this concern. For example, there was a common perception that WBLT 
encouraged students to give preference to other commitments because a backup was available, as exemplified by this comment:

Students seem slightly more willing to skip class when other pressures come up (e.g., work) as they know they can catch up via the iLecture recording.

Lecturers were concerned about the impact on internal students of non-attendance, including their inability to keep up with crowded curricula, engagement with the content and the continuity of lectures and tutorials. This concern about attendance was not shared by the students in the study. When students were asked why they didn't attend face to face lectures, $68.3 \%$ of the 331 respondents agreed or strongly agreed with the statement I could learn just as well using WBLT as face to face. The corresponding item was rated lowest by staff, with only five (3.6\%) agreeing with this statement.

Adding to lecturer's concern with non-attendance was the impact it is having on the lecture dynamic and other teaching and learning activities. The lack of immediate feedback to students was raised as a concern in open ended comments and interviews, yet there were few examples of lecturers' attempts to introduce other methods to compensate for this and other changes. This may be because there is still a tendency to see lectures primarily as a means of delivering content. We found that those lecturers who scored highly on the 'Information Transmission, Teacher Focus' aspect of the Trigwell \& Prosser's (2004) Approaches to Teaching Inventory scale, were less likely to agree that WBLT could help them provide a conceptual framework for their students or enhance their capacity to motivate and communicate with their students. These lecturers were also less likely to agree that students could learn just as well from WBLT as face to face lectures.

Our research suggests that WBLT is highlighting the need for academics to reconsider the role of lectures in supporting blended learning. With some students being offered the technologies and choosing not to attend, some academics have begun questioning the role of lectures. McGarr (2009) has suggested that the nature of the material presented and the pedagogical context from which it emerges is key to this questioning. Within the staff responses to issues raised within this study it seems that student responses to WBLT are promoting academic reflection on the pedagogical value of the lecture. A range of lecturers' responses to changing attendance patterns, for example, emerged from the study. These included restructuring units to replace lectures with more interactive tutorials or workshops, replacing some face to face lectures with additional tutorials and providing the lecture materials as prerecordings. In contrast, one interviewee had introduced roll taking to encourage students to attend lectures.

The research indicates that lecturers and students have different perceptions of the role of lectures. While students find WBLT valuable as a back up and as a study tool, they still appreciate lectures as motivating, providing contact with lecturers and peers and they find the visual aids helpful. For students, the use of WBLT doesn't necessarily exclude lecture attendance.

In contrast, some of the lecturers indicated that they value being able to determine the content students receive, from a quality perspective. One interviewee commented that:

I implemented lectures in order to bring the students together and to make sure that everybody is at least getting (structured content). 
Although the face to face lecture experience is changing due to WBLT, and in some contexts the role of lectures is being questioned, we found that WBLT can be effective tools when their use matches their purpose - to support the traditional lecture experience. They are most appropriate when:

- the lecture is delivered in a traditional format based largely on one-way communication;

- class sizes are large and tend to be impersonal; and there are little to no interactive elements where students communicate or collaborate with others;

- students cannot attend for bona fide reasons - sickness, timetabling, distance from campus;

- students are seeking flexibility in attendance due to work, family and other lifestyle arrangements;

- students come from non-English speaking backgrounds or have special learning needs which make understanding and comprehending real-time lectures difficult.

Some of the contexts in which WBLT are less applicable are when:

- learning experiences and outcomes are best achieved through a physical presence, for example where social communication, networking, socialisation and collaboration are key outcomes;

- the face to face encounter is used for problem solving, discussions and other small group activities;

- the lecture contains confronting, disturbing, confidential or sensitive content that is best discussed in an environment where students' reactions can be monitored and responded to on the fly;

- the lecture requires copyrighted elements that cannot be broadcast through the Internet;

- the lecturer uses video and other multimedia content that WBLT are not able to capture; and

- classes are small and a physical presence is desirable.

\section{The changing nature of teaching when technologies are introduced into the curriculum}

Participants in the staff survey were asked about their perceptions of the use of WBLT for teaching and learning. There was a mixed response about experiences, with $54 \%$ of respondents finding use of WBLT to be generally positive, while another $26 \%$ found the experience to be negative.

The findings of the research indicate a correlation between choice and positive experience with WBLT. Those lecturers who reported having little sense of choice regarding the implementation of WBLT, due to pressures from the institution or their students, were more likely to disagree that their experiences had been positive. This seems to suggest that much of the negative discourse of WBLT is related to the lecturers' sense of control over their choice in using WBLT. If they felt pressured to use WBLT, they reacted negatively towards it, impacting on their perceptions about the usefulness of the tools and their effectiveness.

Despite the mixed response, lecturers were consistent in supporting WBLT for use by external students, whom they recognised as a distinct cohort falling into the category 
of not being able to come to class. The use of WBLT in this context was seen as beneficial to these students particularly for:

- providing up to date information;

- increasing a sense of belonging; and

- providing opportunities for interactions between staff and other students.

Interviews and open-ended comments indicate that whilst lecturers use WBLT in the resources they offer external students, there is concern that WBLT could be detrimental for internal students, as typified by this comment:

For internals I think it can help them to justify not coming to lectures. They think, "it's OK not to go, I'll listen to the iLecture later". I fear later never comes or comes too late and they cram for assessment. Externals, however, brilliant!

Overall, the data suggests that lecturers perceive differences in the benefits for internals and externals. It seems they recognise the benefits for external and part time students, but are not sure of the benefits to on campus students and are concerned about lecture attendance trends. With $75.3 \%$ of students listening because they couldn't attend at times, this concern is well founded. However, rather than focusing on the lecture and ways of maintaining its traditional face to face delivery, lecturers may need to adapt the delivery of the curriculum and explore new approaches to teaching to accommodate the lifestyle influences and needs of students.

The introduction of any new technology affects the whole teaching and learning context (Gosper, Woo, Muir, Dudley \& Nakazawa, 2007). WBLT could have acted as the catalyst for change, however the findings suggest that this has not happened:

- $43.2 \%$ of staff respondents had not changed their lecturing style;

- $36.7 \%$ had not changed what they do in their lectures;

- $74.9 \%$ had not changed the structure of their unit.

The lecturers who indicated that they have changed their practice are the ones who used WBLT to support students who cannot attend class. These were also the lecturers who reported generally positive experiences with WBLT. Some examples include acknowledging the needs of listeners when using visual aids and integrating WBLT with other technologies, for example online discussions.

In one of the staff interviews, the benefits of broadening the range of collaboration opportunities between external and internal students were highlighted:

I started directly talking to the external students during (WBLT) recording... I could
ask questions in a lecture and within an hour or two externals have heard the lecture,
heard the question and posted on the discussion forum their responses to the
questions, so it's more of a united group of students now.

The same lecturer described efforts to provide online equivalent experiences for the external students in his cohort, such as posting a photo where internal students had brought along an item to class. The lecturer found that there were signs that a community was being built between internal and external students, whereas in his previous experiences with the unit, these cohorts had remained quite separate. He reported that "the students are helping each other more and more, not just with concepts but also supporting each other emotionally". 


\section{Conclusion}

WBLT has provided a lens through which to view the complex and changing nature of university teaching and learning. These changes include the new roles for students and staff; the need to consider curriculum design with technologies; and the changing roles of lectures in technology rich environments.

WBLT has the ability to magnify trends; for example, dropping attendance and the changing student profile. Students believe they can learn just as well using these technologies and appreciate the flexibility they offer. Rather than adhering to a predetermined mode of enrolment, students can exercise their ability to choose whether to attend face to face lectures. The technology allows the blending of the two modes of study and students are beginning to do this, whether lecturers want them to or not. In the future, some units of study may not need to make the distinction between the two, whereas others may need to continue clearly distinguishing between the two; for example units that need specialised laboratory or practical sessions.

The research also indicates the need for lecturers to be more reflective in examining their own roles and the roles of lectures in light of the changing needs of students. With many students indicating that face to face attendance is neither possible nor ideal, the focus needs to shift to improving the experience of the learners, and making the most of the valuable face to face time for what it is most useful. In order to maximise student learning, lecturers need to make decisions about what role lectures should play, and what roles supporting technologies should play in the design of curriculum.

Also emerging from the study is the need for teaching staff to carefully manage student expectations. In particular, they need to clearly articulate what is involved in learning for the particular unit of study, what role the lectures and other activities play in the learning process, and the role technologies play in supporting learning. This will help students to manage their learning and meet the expectations of the teaching staff.

\section{Acknowledgments}

Support for this publication has been provided by The Australian Learning and Teaching Council, an initiative of the Australian Government's Department of Education, Science and Training. The views expressed in this publication do not necessarily reflect the views of The Australian Learning and Teaching Council.

\section{References}

Anderson, M. J. (2006). Degree of fit: University students in paid employment, service delivery and technology. Australasian Journal of Educational Technology, 22(1), 88-103. http: / / www.ascilite.org.au/ajet/ajet22/anderson.html

Biggs, J., Kember, D. \& Leung, D. Y. P. (2001). The revised two-factor Study Process Questionnaire: R-SPQ-2F. British Journal of Educational Psychology, 71, 133-149.

Chang, S. (2007). Academic perceptions of the use of Lectopia: A University of Melbourne example. In ICT: Providing choices for learners and learning. Proceedings ascilite Singapore 2007. http: / / www.ascilite.org.au/conferences/ singapore07/procs/chang.pdf 
Craig, P., Wozniak, H., Hyde, S. \& Burn, D. (2009). Student use of web based lecture technologies in blended learning: Do these reflect study patterns? In Same places, different spaces. Proceedings ascilite Auckland 2009.

http: / / www.ascilite.org.au/conferences/auckland09/procs/craig.pdf

Creswell, R. (2003). Research design: Qualitative, quantitative and mixed methods approaches. Thousand Oaks, CA.

Donnan, P., Kiley, M., \& McCormack, C. (2004). Lecture streaming: Getting the pedagogy right. In OLT 2004 (pp. 44-52). Queensland, Australia.

Fardon, M. (2003). Internet streaming of lectures: A matter of style. [viewed 22 Mar 2007, verified 26 Sep 2010] http: / / www.lectopia.com.au/misc/Fardon_MatterOfStyle.pdf

Galusha, J. M. (1997). Barriers to learning in distance education. Interpersonal Computing and Technology, 5(3), 6-14. http: / / www.emoderators.com/ipct-j/1997/n4/galusha.html

Gosper, M., McNeill, M. and Woo, K. (2010) Harnessing the power of technologies to manage collaborative e-learning projects in dispersed environments. Journal of Distance Education, 24(1), 167-186. http: / / www.jofde.ca/index.php/jde/article/view/642/1052

Gosper, M., McNeill, M., Preston, G., Phillips, R., Green, D. \& Woo, K. (2008). The impact of webbased lecture technologies on current and future practices in learning and teaching. Project report. http: / / www.cpd.mq.edu.au/teaching/wblt/ research/report.html

Gosper, M., McNeill, M., Woo, K., Phillips, R., Preston, G. \& Green, D. (2007). Web-based lecture recording technologies - Do students learn from them? Invited presentation at Educause Australasia, 29 Apr - 2 May, Melbourne, Australia.

http:// www.cpd.mq.edu.au/teaching/wblt/docs/dissemination/Educause_Gosper.pdf

Gosper, M., Woo, K., Muir, H., Dudley, C. \& Nakazawa, K. (2007). Selecting ICT-based solutions for quality learning and sustainable practice. Australasian Journal of Educational Technology, 23(2), 227-247. http: / / www.ascilite.org.au/ajet/ ajet23/gosper.html

Johnson, L., Levine, A. \& Smith, R. (2009). The 2009 Horizon Report. Austin, Texas: The New Media Consortium. http: / wp.nmc.org/horizon2009/

Lectopia (2007). Licensing. [viewed March 2009] http: / / ilectures.uwa.edu.au/licensing.lasso

Lefoe, G. \& Albury, R. (2004). Editorial. Educational Media International, 41(3), 181-182.

Lefoe, G. \& Hedberg, J. (2006). Blending on and off campus: A tale of two cities. In C. Bonk \& C. Graham (Eds.), Handbook of blended learning environments: Global perspectives, local designs. Pfeiffer: San Francisco, pp325-337.

Maag, M. (2006). iPod, uPod? An emerging mobile learning tool in nursing education and students' satisfaction. In Who's learning? Whose technology? Proceedings ascilite Sydney 2006. http: / / www.ascilite.org.au/conferences/sydney06/proceeding/pdf_papers/p92.pdf

Massingham, P. \& Herrington, T. (2006). Does attendance matter? An examination of student attitudes, participation, performance and attendance. Journal of University Teaching $\mathcal{E}$ Learning Practice, 3(2). http:/ / ro.uow.edu.au/jutlp/vol3/iss2/3/

McElroy, J. \& Blount, Y. (2006). You, me and iLecture. In Who's learning? Whose technology? Proceedings ascilite Sydney 2006.

http:/ / www.ascilite.org.au/conferences / sydney06/proceeding/pdf_papers/p87.pdf 
McGarr, O. (2009). A review of podcasting in higher education: Its influence on the traditional lecture. Australasian Journal of Educational Technology, 25(3), 309-321. http:/ / www.ascilite.org.au/ajet/ajet25/mcgarr.html

McInnis, C. \& Hartley, R. (2002). Managing study and work: The impact of full-time study and paid work on the undergraduate experience in Australian universities. Department of Education, Science and Training. Commonwealth of Australia. http:/ / www.dest.gov.au/archive/highered/eippubs/eip02_6/eip02_6.pdf

McNeill, M., Woo, K., Gosper, M., Phillips, R., Preston, G. \& Green, D. (2007). Using web-based lecture technologies - advice from students. In Enhancing Higher Education, Theory and Scholarship, Proceedings of the 30th HERDSA Annual Conference Adelaide, 8-11 July. http: / / www.herdsa.org.au/wp-content/ uploads / conference/2007/ papers/ p125.pdf

Palmer, S. \& Holt, D. (2009). Staff and student perceptions of an online learning environment: Difference and development. Australasian Journal of Educational Technology, 25(3), 366-381. http:/ / www.ascilite.org.au/ajet/ajet25/palmer.html

Phillips, R. (2005). Challenging the primacy of lectures: The dissonance between theory and practice in university teaching. Journal of University Teaching and Learning Practice, 2(1). http:// ro.uow.edu.au/jutlp/vol2/iss1/2/

Phillips, R. (2006). Tools used in learning management systems: Analysis of WebCT usage logs. In Who's learning? Whose technology? Proceedings ascilite Sydney 2006. http: / / www.ascilite.org.au/conferences/sydney06/proceeding/pdf_papers/p208.pdf

Phillips, R., Gosper, M., McNeill, M., Woo, K., Preston, G., \& Green, D. (2007). Staff and student perspectives on web based lecture technologies: Insights into the great divide. In ICT: Providing choices for learners and learning. Proceedings ascilite Singapore 2007. http: / / www.ascilite.org.au/conferences/ singapore07/procs/phillips.pdf

Signor, L. (2003). An exploration into the reactions of undergraduate students to virtual lectures. Paper presented at OLT 2003, Queensland, Australia.

Simpson. (2000). Supporting students in open and distance education. UK: Kogan Page.

Soong, S. K. A., Chan, L. K., Cheers, C. \& Hu, C. (2006). Impact of video recorded lectures among students. In Who's learning? Whose technology? Proceedings ascilite Sydney 2006. http: / / www.ascilite.org.au/conferences / sydney06/proceeding/pdf_papers/p179.pdf

Trigwell, K. \& Prosser, M. (2004). Development and use of the Approaches to Teaching Inventory. Educational Psychology Review, 16(4), 409-424.

von Konsky, B. R., Ivins, J. \& Gribble, S. J. (2009) Lecture attendance and web based lecture technologies: A comparison of student perceptions and usage patterns. Australasian Journal of Educational Technology, 25(4), 581-595.

http: / / www.ascilite.org.au/ajet/ajet25/vonkonsky.html

Williams, J. \& Fardon, M. (2005). On-demand internet-transmitted lecture recordings: Attempting to enhance and support the student experience. Proceedings of ALT-C 2005 (Manchester, September 2005), Association for Learning Technology, 153-161.

Williams, J. \& Fardon, M. (2007). Perpetual connectivity: Lecture recordings and portable media players. In ICT: Providing choices for learners and learning. Proceedings ascilite Singapore 2007. http: / / www.ascilite.org.au/conferences/ singapore07/ procs/williams-jo.pdf

Woo, K., Gosper, M., McNeill, M., Preston, G., Green, D. \& Phillips, R. (2008). Web-based lecture technologies: blurring the boundaries between face-to-face and distance learning. ALT-J: Research in Learning Technology, 16(2), 81-93. 


\section{Greg Preston \\ Lecturer in Educational ICT and e-Learning \\ School of Education, The University of Newcastle \\ Email: Greg.Preston@newcastle.edu.au}

Associate Professor Rob Phillips

Educational Development Unit, Murdoch University

Email: r.phillips@murdoch.edu.au

Fellow, Higher Education Research and Development Society of Australasia

Associate Professor Maree Gosper PhD

Director, Technologies in Learning and Teaching

Learning and Teaching Centre, Macquarie University

Email: maree.gosper@mq.edu.au

Web: http: / / www.mq.edu.au/ltc/about/staff/mgosper.htm

Margot McNeill

Lecturer in Higher Education Development

Learning and Teaching Centre, Macquarie University

Email: margot.mcneill@mq.edu.au

Web: http: / / www.mq.edu.au/ltc/about/staff/mmcneill.htm

Karen Woo

Centre for Professional Development

Institute of Higher Education Research \& Development, Macquarie University

Web: http:/ / www.mq.edu.au/ltc/about/staff/kwoo.htm

David Green

Director Educational Technologies, Flinders University

Email: david.green@flinders.edu.au

Web: http: / / www.flinders.edu.au/people/david.green 